\title{
Ethnobotanical study of medicinal plants used against sickle cell anaemia in the eastern part of the Côte d'Ivoire
}

Akakpo-Akue J', Kplé T.K.M., ${ }^{1}$, Coulibaly Kiyinlma ${ }^{3}$, AHON Gnamien Marcel ${ }^{1,5}$, Fofié Yvette $^{3}$. Yapo -Crezoit. A. ${ }^{2}$ ZIRIHI Guédé, Noël ${ }^{6}$, Kra A. K.M. ${ }^{1}$

${ }^{1}$ Laboratory of Biology and Health, UFR Biosciences, Université Félix Houphouët-Boigny (UFHB), 22 BP 582 Abidjan

01, Côte d'Tvoire.

2 Immunity Biology Center, Institut Pasteur de Côte d'Ivoire, 01 BP 490 Abidjan 01, Côte d'Ivoire.

3Pharmacognosy laboratory, UFR of Pharmaceutical and Biological Sciences, Université Félix Houphouët-Boigny, Côte d'Ivoire.

${ }^{4}$ Département de Biologie Végétale, UFR of Biological Sciences, University Péléforo-Gbon-Coulibaly, Côte d'Ivoire

${ }^{5}$ National Pedagogical Institute for Technical and Vocational Education

${ }^{6}$ Laboratoire de Botanique, UFR Biosciences, Université Félix Houphouët-Boigny de Cocody Abidjan. 22 BP

Corresponding Authors: tatianakangah1@gmail.com 27 BP 1079 Abidjan 01, (+225 57459198) Côte d'Ivoire

Keywords: Ethnobotanical, Medicinal plants, Sickle cell anaemia, Côte d'Ivoire.

Publication date 31/07/2020, http://m.elewa.org/Journals/about-japs/

1 SUMMARY

An ethnobotanical survey was conducted to record the various plant families, species, and plant parts used to manage sickle cell disease in the Indenié-Djouablin region eastern Côte d'Ivoire. Nine traditional healers aged 36 to 67 years old were selected in six different villages according to their reputation in knowledge of traditional medicine, their availability and their willingness to share information. A total of 26 species of plants belonging to 20 families were reported to have antisickling activity. Eleven (11) different medication recipes were composed from these 26 species of plants ((Afromonum melegueta (Roscoe) K. Schum., Xylopia aethiopica) mainly). The main plant parts used were stem bark $(38 \%)$ followed by fruit $(18 \%)$ and seeds $(18 \%)$. The majority of the main plants recorded $(84.61 \%)$ were wild. From the recorded plants, $65.38 \%$ were trees and $23.07 \%$ shrubs. Most remedies $(82 \%)$ were made up by decoction and were employed orally $(54 \%)$ or by enema $(32 \%)$. The potential anti-sickling activity of the plant species recorded during this study could be the effect of alkaloids, polyphenols, quinones and terpenoids compounds found during the phytochemical screening of the 26 plants species.

\section{INTRODUCTION}

Sickle cell disease (SCD) or sickle cell anaemia (SCA) is an autosomal recessive genetic blood inherited disorder. SCA results from a point mutation in the $\beta$-globin gene that leads to the substitution of a hydrophilic glutamic acid by a hydrophobic Valine residue, at the sixth position of the $\beta$-chain of haemoglobin molecule. This mutation leads to the transformation of Haemoglobin A (HbA) to Haemoglobin S (HbS)
(Bindon, 2004). Under hypoxic situation, homozygous individuals could suffer from pains due to vaso-occlusive crises, hemolytic anaemia and increased sensitivity to infections (Galacteros, 1997; Girot et al., 2003, Thuret et al., 2010). In Côte d'Ivoire, the magnitude of this disease results in a prevalence rate of about $14 \%$ of the total population and $2 \%$ representing the severe forms (Tolo et al., 2010; Sawadogo et al., 
2014). In Côte d'Ivoire, as in other developing countries, the difficulties of accessing primary health care and the reduced financial means, leads $80 \%$ of the population to use medicinal plants for the treatment of different diseases (Ngbolua et al., 2011 a; b). Despite the reliance on plants for the treatment of human health diseases in Côte d'Ivoire, there have been no

\section{MATERIEL ET METHODES}

3.1 Study area: The area studied was in the east of Côte d'Ivoire in the Indenié-Djouablin region (6 $6^{\circ} 43^{\prime} 47^{\prime \prime}$ North and $3^{\circ} 29^{\prime} 47^{\prime \prime}$ West). The survey covered six villages: N'gra, Kouakou-Dramankro, Abro-Namue, Adaou, Amoriakro, and Ebakro. The studied area was bounded to the north by the region of Gontougo and Iffou to the west by the region of N'Zi, to the south by the region of $\mathrm{Me}$ and to the east by the Republic of Ghana. The region covers an area of $6,919.55 \mathrm{~km}^{2}$. The recent General Census of Population and Housing recorded a population of about 700,000 inhabitants in Indenié-Djouablin (Rgph, 2014). The survey's area is located in the Guinean part of Côte d'Ivoire characterized by the densest water system and forest (Rgph, 2014). With a subequatorial climate, the studied area has a culturable area favourable for food and industrial crops. The population of IndeniéDjouablin is characterized by the presence of several large ethnic groups (Agni, Malinkés, Baoulés, N'Zima, Abourés,). The rest of the population is made up of the other ethnic groups in Côte d'Ivoire and the allogenous who came mainly from countries in the sub-region (Burkina Faso, Ghana, Benin, Togo and Niger). 3.2 Vegetable and technical material: The twenty-eight main plants species from the survey represented the vegetable material. Guided by the healers, classic material such as knife and machete were used to collect some plants samples in order to conduct the chemical empirical studies to document the indigenous knowledge and specific plant species used by traditional healers to treat sickle cell anaemia. This study was initiated in order to identify the medicinal plants that are used by traditional healers in the management of Sickle cell disease in South Eastern Côte d'Ivoire.

study and to build up a collection of dried plants for future reference.

\subsection{Methods}

3.2.1 Ethno-medicinal survey: The information summarized in the present paper was compiled from 6 villages in the IndeniéDjouablin regions (Figure 1). The methodology followed in the field surveys is based on Fujita et al., (1995). The data was collected through semistructured interviews performed with local people (Martin, 1995). After explaining the purpose of the visit, a questionnaire in French was proposed. If the French level of the respondent was low, the questionnaire was translated into the local language. A total of 09 people were surveyed. The informants were questioned two times, which helped checking the information already collected. Information gathered on various data such as local names, plant part used, therapeutic effect, diseases treated, methods of preparation, methods of administration, duration of treatment and traditional cultivation techniques were obtained and recorded. Questions about the traditional healers' personal information were also asked. Field trips were conducted with the interviewees to collect specimens of the plants. A photographic archive of the observed species was created to help the identification. The collected samples were identified at the National Floristic Center (C.N.F.), by their scientific and family name and their botanical characteristics. All the results were listed Table 2 and 3 . The card was made with the software ArcGIS 10.5 


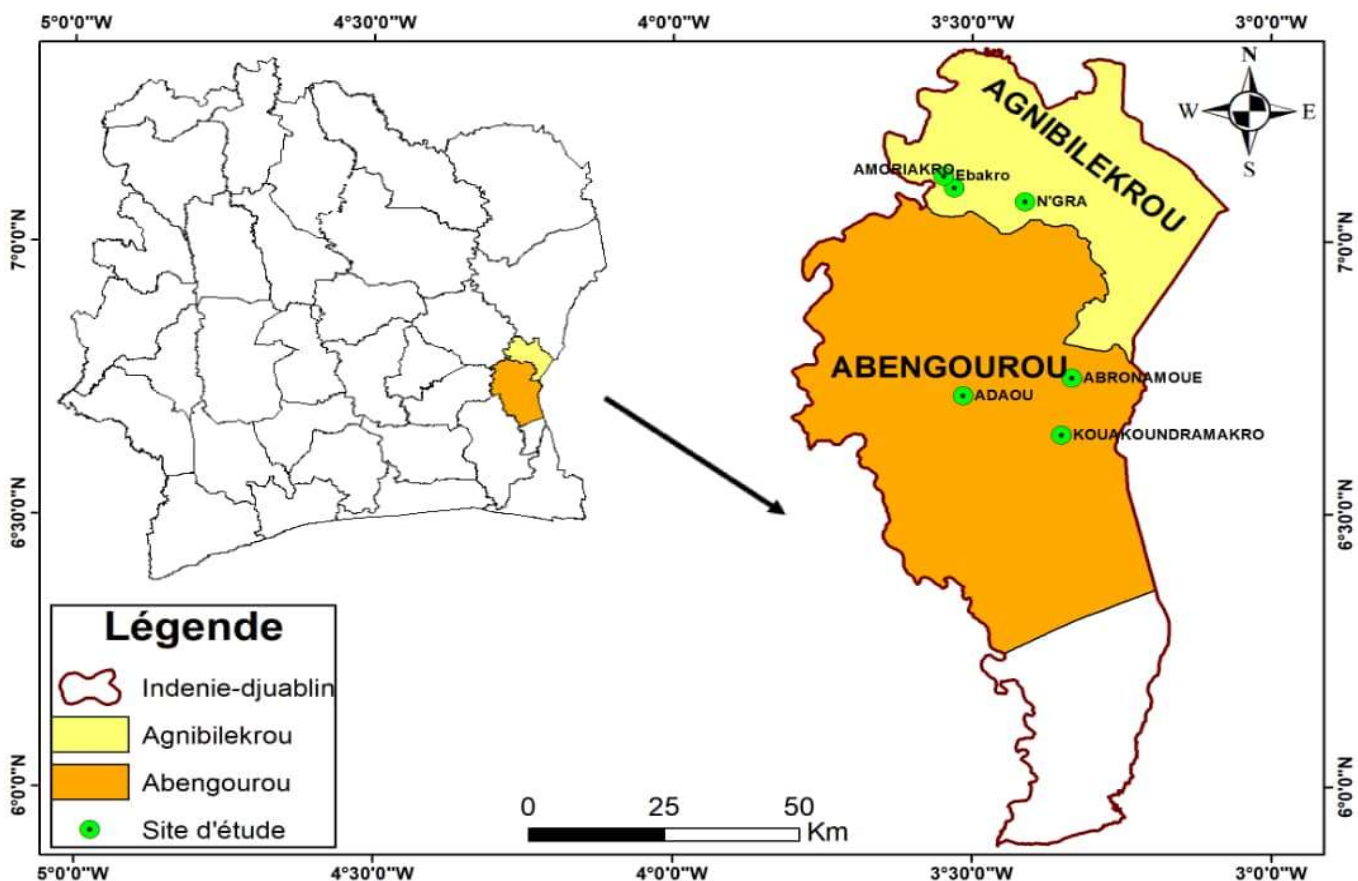

Figure 1: Geographical location of the study area (software ArcGIS 10.5)

\subsubsection{Preparation of the plant extracts}

3.2.2.1 Getting powder from each plant: The different parts of the collected plants were washed, cut and dried at room temperature (25$30^{\circ} \mathrm{C}$ ) in the Biochemistry Laboratory at University Félix Houphouet-Boigny, during 3 weeks. The dried plant material was pulverized, using an electric crusher and used to prepare aqueous extract and hydro-ethanolic extract.

\subsubsection{Preparation of Aqueous Extract (AE)} and hydro-ethanol extract (HEE): Zirihi et al.,
(2003) was used for the preparation of both extracts

3.2.3 Characterization of the chemical groups: Major groups of secondary metabolites such as sterols, polyterpenes, alkaloids, tannins, polyphenols, flavonoids, quinones, and saponins were characterized by classical methods described by Nemlin and Brunel, (1995) and Békro et al., (2007).

Table1: Reagents and tests of characterization of the chemical groups

\begin{tabular}{|c|c|c|}
\hline Secondary metabolites & Reagents & $\begin{array}{l}\text { Reaction indicating that the test is } \\
\text { positive }\end{array}$ \\
\hline Alkaloids & Dragendorff & Precipitate or orange colouring \\
\hline Flavonoids & Cyanidine & Reddish-brown precipitate \\
\hline Polyphenols & Ferric chloride & $\begin{array}{l}\text { Heat then pink-orange or purplish } \\
\text { colouring }\end{array}$ \\
\hline Quinones & Bornstraegen & Blackish-blue or green \pm dark colouring \\
\hline Saponosides & Foam Test & Persistent foam, higher than $1 \mathrm{~cm}$ \\
\hline Sterols and Polyterpenes & Liebermann & $\begin{array}{c}\text { Crimson or purple ring, changing blue } \\
\text { then green }\end{array}$ \\
\hline Tannins & Stiasny & $\begin{array}{l}\text { Catechic : precipitate in large flakes } \\
\text { Gallic : blue-black deep colouring }\end{array}$ \\
\hline
\end{tabular}




\section{RESULTS AND DISCUSSION}

4.1 Demographic profile of traditional medicine practitioners: During this ethnomedicinal study conducted in IndeniéDjouablin region of eastern part of Côted'Ivoire, 9 traditional healers were interviewed. Native of 6 villages, the traditional healers have collaborated in this study by providing information on antisickling plants they were using to treat people. All the informants knew and described perfectly SCD's symptoms: vaso-occlusive crisis, frequent anaemia, yellow eyes, and retarded growth. One (1) man and eight (8) women were interviewed. The oldest person of these healers was a woman about 70 years old and the youngest was a man about 39 years old. The interviewed that were between 30 and 50 years of age represented $44 \%$ and those between 50 and 85 years old represented $56 \%$. Only $17 \%$ of the respondents could read. The remaining 83\% never attended school.

\subsection{Ethnobotanical characteristics of} the studied plants: The study made it possible to identify 26 species of plants used in traditional medicine to treat sickle cell anaemia (Table 2). These 26 species of plants were composed of 20 family. Five (5) families: Annonaceae, Apocynaceae, Bignoniaceae, Rutaceae and Rubiaceae were the most used. The most used species by the tradiditionnal hales were were Afromonum melegueta (Roscoe) K. Schum. (17, $94 \%$ ), Xylopia aethiopica (15. 38 $0 \%)$, Ceiba pentandra (4.8\%) and Nauclea latifolia $(4.8 \%)$. This result was not observed in other parts areas of Côte-d'Ivoire. N'guessan et al., (2009), working on the phytochemical screening of some Ivorian medicinal plants used in the department of Agboville (Côted'Ivoire), did not mention any plants species that have antisickling activity. As for, Ouattara et al., (2016) investigating the floristic diversity and uses of medicinal plants in the Sudanese area of the northwest of the Côte d'Ivoire, he noted that 3 plants species representing 5.7\% of the total plants, were reported to be effective in the treatment of sickle cell anaemia. Two (02) of the 3 plants species, Khaya senegalensis and Zanthoxylum zanthoxyloides were reported in the present study were of the same genus as the specie Zanthoxylum leprieuri and Zanthoxylum gilletii. This variability in the results would be due to the specific topic, which is the ethnobotanical survey of the plant used against sickle cell disease in the present survey. In other western parts of Africa, the survey of Gbadamosi, (2015) was made among 20 traditional medicine practitioners. In this study, 60 plant species from 32 families were identified to fight against SCD. Among the most frequently. Were Afromonum melegueta (Rosc) K. Schum. (8\%), Xylopia aethiopica (Dunal) A. Rich. (13\%), and Zanthoxylum zanthoxyloides (Lam.) Zepern and Timler (11\%) In the present study representing the most divulged species with their percentage frequency were Afromonum melegueta (Roscoe) K. Schum. (17.94\%), Xylopia aethiopica (Dunal) A. Rich. (15. $38 \% \%$ ) and Zanthoxylum zanthoxyloides (Lam.) Zepern and Timler (2. 43 \%). Zanthoxylum leprieuri, zanthoxylum gilletii, Khaya senegalensis and Solanum torvum representing $4.8 \%$ were found having the same genus and family that some plants from Gbadamosi, (2015). Finally, 37\% of the plant species listed in the present study were present in the list of plants of the investigation of Gbadamosi, (2015). Working on a review of Medicinal Plants used for the Treatment of Sickle Cell Disease in the Democratic Republic of Congo, Mpiana et al., (2012) found 53 plant species growing spontaneously which were prescribed by traditional healers for their potential against sickle cell disease. This different results would be due to the use of different methods of investigation and different number of informants

4.3 Some traditional recipes used for the management of sickle cell disease: Eleven (11) recipes were made up from the 26 species that were reported to be effective in the management of sickle cell disorder in the study area (Table 3). Ten (10) multi-plants recipes representing $91 \%$ are mainly used compared 
to the nine percent $(9 \%)$ mono-plant recipes. However, Gbadamosi, et al., (2012) has highlighted the efficacy and steady antisickling activity of mono-plant recipe composed of Phyllanthus amarus Schumach. \& Thonn. The patient could take an advantage by using the monospecific receipts because the combination of several plants recipes could sometimes be dangerous. In Africa, about 30 $\%$ of fatal accidents are caused by mixtures (Béné et al., 2016).

\section{4 preparation and administration of} traditional medicines: All the plants parts were used. The stem (38\%) was the most used followed by fruit (18\%), seed (18\%), leaf (17 $\%)$ and roots $(9 \%)$. This result is different from that of Gbadamosi, (2015). This author showed that the leaves were the most used in Oyo State in Nigeria (32\%), followed by root $(24 \%)$, fruit $(15 \%)$, bark $(15 \%)$, seed $(7 \%)$, rhizome $(3 \%)$ and bulb (4\%). Amujoyegbe et al., (2016) also has determined that the leaves are first used (69. 10\%) followed by the root
(17. 98\%) in Southern Nigeria. Both these two last authors had the same trend according to the percentage of the plant parts used. The difference between those results and this present study could be explained by the study area. The study of the former authors were both located in the same country, which was different from Côte d'Ivoire. Also, using the leaves has its advantage. As Poffenberger et al., (1992) wrote, $50 \%$ of the leaves could be harvested without affecting the survival of the plant. The canary, the flat stone, the pebble, the mortar and the pestle are used to prepare the medication recipes. The decoction (82\%) is the most used method of preparation. This result looks similar to Amujoyegbe et al., (2016) and Ouattara (2006) who explained that the decoction is only one method use in the department of Divo. The most common way used to administer the medicines is orally (54\%) followed by enema (32\%) and $14 \%$ by cutaneous way. 
Table 2: Plant characteristics obtained in the survey

\begin{tabular}{|c|c|c|c|c|c|}
\hline $\mathbf{N}^{\circ}$ & Scientific names of plants & Family & Morphology & State of plants & $\begin{array}{l}\text { Other therapeutic } \\
\text { Practices }\end{array}$ \\
\hline 1 & Adenia lobata (JACQ) & Passifloraceae & Tree & Wild & $\begin{array}{l}\text { Malaria; anti-inflammatory; } \\
\text { Infection }\end{array}$ \\
\hline 2 & Afromonum melegueta (K.SCHUM) & Zingiberacea & Grass & Wild & Infection \\
\hline 3 & Alstonia boonei (De Wild) & Apocynaceae & Tree & Wild & $\begin{array}{l}\text { anaemia; antihypertensive; } \\
\text { Malaria; anti-inflammatory }\end{array}$ \\
\hline 4 & Annona senegalensis (PERS) & Annonaceae & Tree & Wild & Infection; anaemia; Malaria; pain \\
\hline 5 & Anthocleista djalonensis (AFZEL) & Loganiaceae & Tree & Wild & $\begin{array}{l}\text { Malaria; anti-inflammatory; } \\
\text { Infection }\end{array}$ \\
\hline 6 & Blighia sapida (K.D. KOENIG) & Sapindaceae & Tree & Wild & Anaemia; infection; Pain \\
\hline 7 & Casia sieberiana $(D C)$ & Caesalpiniaceae & Tree & Wild & Anaemia; Malaria; infection \\
\hline 8 & Ceiba pentandra (L.GAERTN) & Bonbacaceae & Tree & Wild & Anaemia; Malaria; infection; typhoide fever \\
\hline 9 & $\begin{array}{l}\text { Distemonanthus benthamianus } \\
\text { (BAILL) }\end{array}$ & Caesalminiaceae & Tree & Wild & $\begin{array}{c}\text { Sexual infection,anaemia; } \\
\text { antihypertensive }\end{array}$ \\
\hline 10 & Grifflonia simplicifolia (DC BAILL) & Fabacea & Shrub & Cultivate & $\begin{array}{l}\text { Cough sore throat, anaemia, } \\
\text { anti-inflammatory; }\end{array}$ \\
\hline 11 & Harungara madagascariensis (LAM) & Rutaceae & Tree & Wild & Anaemia; Malaria; anti-inflammatory; infection \\
\hline 12 & $\begin{array}{l}\text { Holarrhena floribunda } \\
\text { (L. PROTA) }\end{array}$ & Apocynaceae & Tree & Wild & Anaemia; Malaria; anti-inflammatory; infection \\
\hline 13 & Jatropha grosssypiifolia.L & Euphorbiacea & Shrub & Cultivate & Malaria; anaemia; infection scarring \\
\hline 14 & Justicia secunda (VAHL) & Acanthaceae & Shrub & Wild & Anaemia; Antihypertensive \\
\hline 15 & Khaya senegalensis (DESR A.JUSS) & Meliaceae & Tree & Wild & Skin infection; Anaemia; Malaria; Infection \\
\hline 16 & Kigelia africana (PROTA) & Bignoniaceae & Tree & Wild & $\begin{array}{c}\text { Delivery infection; sexual weakness; sexual hormone } \\
\text { regulator }\end{array}$ \\
\hline 17 & Morinda lucida $L$. & Rubiaceae & Shrub & Wild & $\begin{array}{l}\text { Malaria; anaemia; Antimicrobial, infertility Treatment } \\
\text { Female }\end{array}$ \\
\hline 18 & Nauclea latifolia $L$. & Rubiaceae & Tree & Wild & Anaemia; Malaria; infection anti-inflammatory; \\
\hline 19 & Parquetina nigrescens (ALZEL) & Periplocaceae & Liana & Wild & Malaria; anaemia; Eyes pain; kidney pain; delivery \\
\hline 20 & Solanum torvum Sw. & Solanoceae & Shrub & Wild & Anaemia; Infection \\
\hline 21 & Spathodea campanulata (P.Beauv) & Bignoniaceae & Tree & Wild & $\begin{array}{l}\text { Delivery infection; sexual weakness; malaria; prevention of } \\
\text { illnesses }\end{array}$ \\
\hline 22 & Terminalia catapa $L$ & Combretaceae & Tree & Wild & Anaemia; Infection; Pain \\
\hline 23 & Xylopia aethiopica (DUM) & Annonaceae & Shrub & Cultivate & Infection \\
\hline 24 & Zanthoxylum gilletii (DE WILD) & Rutaceae & Tree & Wild & $\begin{array}{l}\text { Anaemia; Malaria; infection antihypertensive; sexual } \\
\text { weakness, anti-inflammatory; }\end{array}$ \\
\hline 25 & Zanthoxylum leprieuri (GUILL) & Hypericaceae & Tree & Wild & $\begin{array}{l}\text { Anaemia; Malaria; infection; antihypertensive; sexual } \\
\text { weakness, anti-inflammatory; }\end{array}$ \\
\hline
\end{tabular}




\begin{tabular}{|c|c|c|c|c|c|}
\hline $\mathbf{N}^{\circ}$ & Scientific names of plants & Family & Morphology & State of plants & $\begin{array}{c}\text { Other therapeutic } \\
\text { Practices }\end{array}$ \\
\hline 26 & Zingiber officinale (Rosc) & Zingiberacea & Grass & Cultivate & Cough sore throat, Infection \\
\hline
\end{tabular}

Table 3: Ethnobotanical characteristics

\begin{tabular}{|c|c|c|c|c|c|c|c|}
\hline & BOTANICAL NAME & FAMILY & $\begin{array}{l}\text { LOCAL } \\
\text { NAME }\end{array}$ & $\begin{array}{l}\text { ETHNIC } \\
\text { GROUP }\end{array}$ & $\begin{array}{l}\text { PLANT PARTS } \\
\text { USED }\end{array}$ & $\begin{array}{c}\text { MODE OF } \\
\text { PREPARATION }\end{array}$ & $\begin{array}{l}\text { ADMINISTRATION, } \\
\text { DOSAGE AND } \\
\text { DURATION OF THE } \\
\text { TREATMENT }\end{array}$ \\
\hline \multirow{4}{*}{1} & $\begin{array}{l}\text { Parquetina nigrescens } \\
\text { (ALZEL) }\end{array}$ & Periplocaceae & Ababagnan & Agni & Leaf / Stem & \multirow{4}{*}{ Decoction } & \multirow{4}{*}{$\begin{array}{l}\text { Oral, drink three glasses a } \\
\text { day indefinitely }\end{array}$} \\
\hline & Justicia secunda (VAHL) & Acanthaceae & Modja waka & Baoule & Leaf Stem Bulb & & \\
\hline & Jatropha gtosssypiifolia L. & Euphorbiacea & Apploplo gna & Agni & Leaf Stem Bulb & & \\
\hline & $\begin{array}{l}\text { Afromonum melegueta } \\
\text { K.SCHUM) }\end{array}$ & Zingiberacea & Essa & Agni & Seed & & \\
\hline \multirow{4}{*}{2} & Kigelia africana (PROTA) & Bignoniaceae & Singian & Malinke & Stem Bark & \multirow{4}{*}{ Decoction } & \multirow{4}{*}{$\begin{array}{l}\text { Oral and enema } \\
\text { until healing }\end{array}$} \\
\hline & $\begin{array}{l}\text { Harungara madagascariensis } \\
\text { (LAM) }\end{array}$ & Hypericaceae & Soulgalani brou & Malinke & Leaf & & \\
\hline & $\begin{array}{l}\text { Zanthoxylum leprieuri } \\
\text { (GUILL) }\end{array}$ & Rutaceae & Bakélé & Baoulé & Stem Bark & & \\
\hline & Xylopia aethiopica (DUM) & Annonaceae & Essidian & Agni & Fruit & & \\
\hline \multirow{8}{*}{3} & Alstonia boanei (De Wild) & Apocynaceae & Grien & Agni & Stem Bark & \multirow{8}{*}{ Decoction } & \multirow{8}{*}{$\begin{array}{l}\text { Oral and enema, drink two } \\
\text { glasses a day indefinitely }\end{array}$} \\
\hline & $\begin{array}{l}\text { Ceiba pentandra } \\
\text { (L.GAERTN) }\end{array}$ & Bonbacaceae & Bana-hiri & Malinké & Stem Bark & & \\
\hline & $\begin{array}{l}\text { Holarrhena floribunda ( } L . \\
\text { PROTA) }\end{array}$ & Apocynaceae & Sèbè & Malinké & Root Bark & & \\
\hline & Nauclea latifolia $L$ & Rubiaceae & Badi des marais & Francais & Root Bark & & \\
\hline & $\begin{array}{l}\text { Zanthoxylum gilletii (DE } \\
\text { WILD) }\end{array}$ & Rutaceae & wô & Agni & Stem Bark & & \\
\hline & $\begin{array}{l}\text { Anthocleista djalonensis } \\
\text { (AFZEL) }\end{array}$ & Loganiaceae & Anoubé & Akyé & Stem Bark & & \\
\hline & $\begin{array}{l}\text { Afromonum melegueta } \\
\text { (K.SCHUM) }\end{array}$ & Zingiberacea & Essa & Agni & Seed & & \\
\hline & Xylopia aethiopica (DUM) & Annonaceae & Essidian & Agni & Fruit & & \\
\hline 4 & $\begin{array}{l}\text { Spathodea campanulata } \\
\text { (P.Beauv) }\end{array}$ & Bignoniaceae & Assrele & Agni & Stem Bark & Decoction & $\begin{array}{l}\text { Oral and enema, drink two } \\
\text { glasses a day for } 1 \text { WEEK }\end{array}$ \\
\hline
\end{tabular}




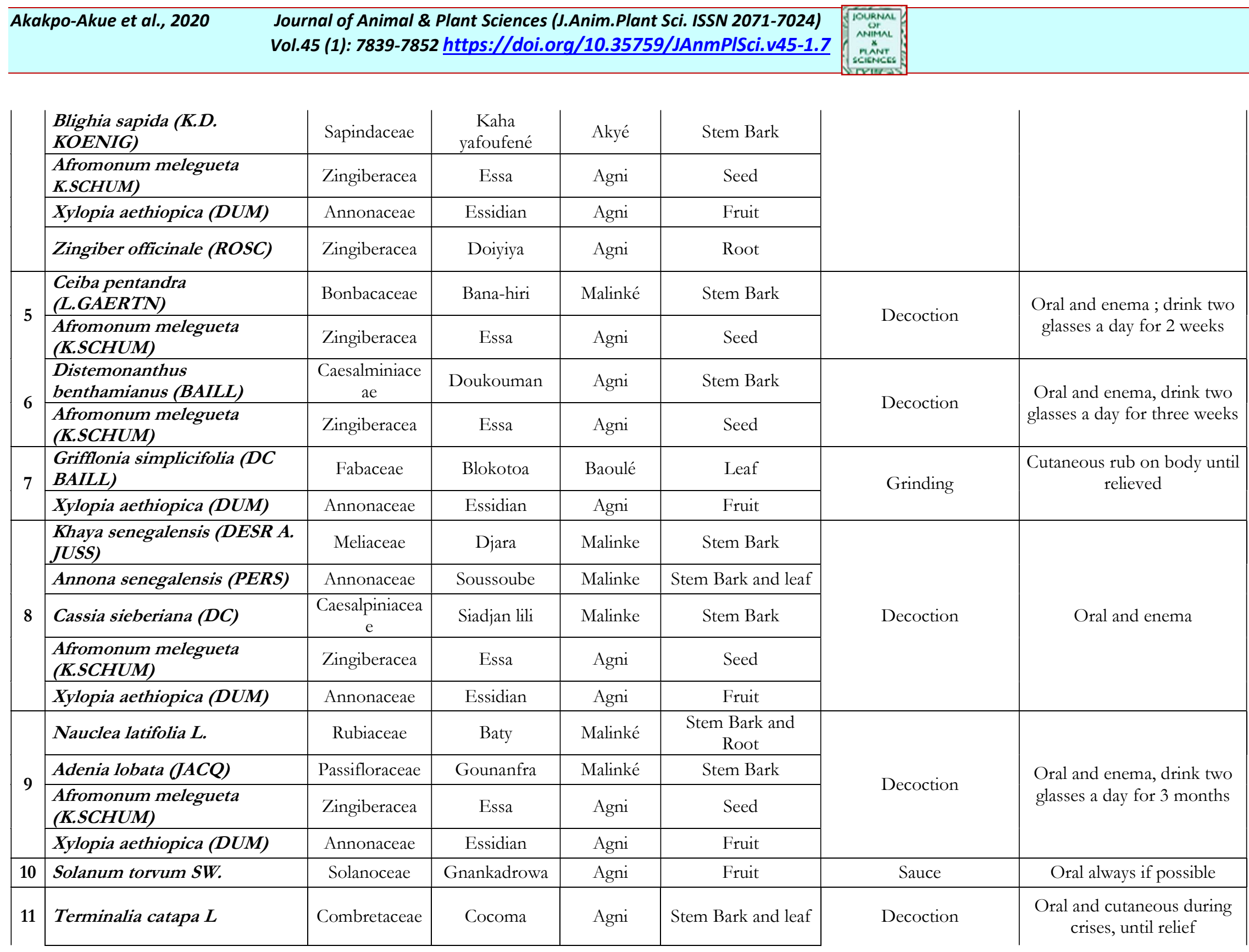


4.5 Antisickling activity of the recorded plants: Besides some ethnobotanical studies carried out in the world, literature presented scientific validation of Antisickling activity concerning some plants recorded in this study. Indeed, the anti-sickling effects of the crude aqueous extract (CAE) of Xylopia aethiopica have been investigated. CAEs exhibited a large antisickling effect by inhibiting HbSS polymerization to $90 \%$. This CAE was also able to reverse sickled erythrocytes and improve $\mathrm{Fe}^{2+} / \mathrm{Fe}^{3+}$ ratio 80 . Thin layer chromatographic analysis highlighted that CAEs contain some anti-sickling amino acids such as Arg, Tyr and Asp at varying concentrations. The total free amino acid concentrations of the samples revealed high concentrations of $1028 \mathrm{mg}$. This author's results suggest that when used as spice in food, Xylopia aethiopica might be a promising option for the effective management of SCD (Uwakwe et al., 2008). Also, Akakpo-Akue et al., (2018), have studied the reversal activity of the aqueous extract of a multi-plant recipe that has been made up of (Jatropha grosssypiifolia, Justicia segunda and Parquetina nigrescens). The results showed that to a concentration of $10 \mathrm{mg} / \mathrm{mL}$ of plant extract, the sickling reversion rate was $80 \%$. Individually, these three plants have also shown antisickling properties. For example, a petroleum ether and aqueous methanol of Parquetina nigrescens showed a protective effect on the membrane and an inhibitory action on the hemolysis of red blood cells (Imaga et al., 2010) and many extracts of Justicia secunda have been studied by Mpiana et al., (2012). As for Harungana madagascariensis Lam. ex. Poir (Hypericaceae), its aqueous and ethanolic extracts display $42 \%$ inhibitory of the polymerization and 52\% reversal activities of the erythrocytes (Fatokun et al., 2015). Moreover, the antisickling activiy of Zanthoxylum gilletii De Wild. K. senegalensis were respectively studied by Elekwa et al., (2005) and Fall et al., (1999). As for Mpiana et al., (2007) these authors investigated the anti-sickling activity of Afromomum albo violaceum, Annona senegalensis and Ceiba pentandra, and T. catappa by Chikezie, (2011).

\subsection{Phytochemical and pharmacological} characteristics: The two extracts (aqueous and hydro-ethanolic) of the 26 plant species contain all the chemical groups of secondary metabolites (Table 4). Only quinone was not revealed in the majority of the two plant extracts. Both solvents concentrate the secondary metabolite alike. Indeed the presence of phenols is common in most plants. Flavonoids are well known to in influence enzymes activity in several biological processes (Ghedira, 2005). Moreover, the presence of alkaloids is a great therapeutic interest because of their pharmacological and biological properties. Alkaloids could also have anti-inflammatory, antioxidant and antibacterial properties (Karou, 2006). Recently Ngbolua et al., (2015) showed antisickling activity of a polyterpene (lunaric acid). Indeed, this poly-terpene associated with anthocyanins would prevent the peroxidation of membrane lipids and thus prevent erythrocyte lysis and inhibit the polymerization of haemoglobin $\mathrm{S}$ by engaging in a reaction with this protein, which would be competitive. Other authors have shown these same activities of triterpenes such as betulinic, maslinic, oleanolic (Tshibangu, 2011) and ursolic acid (Tshilanda et al.; 2015). All the results of the phytochemical screening would partly explain the prescription of these plants as therapeutic means. A drug based on these compounds could provide sickle cell patients with seizure spacing since most of these compounds have antiinflammatory, anti-analgesic, anti-oxidant, antianaemic antisickling, and anti-infectious activity. 
Table 4: Table showing phytochemical screening of the 26 plants species selected for the study

\begin{tabular}{|c|c|c|c|c|c|c|c|c|c|c|c|c|c|c|}
\hline \multirow[b]{2}{*}{ Plants } & \multicolumn{7}{|c|}{ AQUEOUS EXTRACT } & \multicolumn{7}{|c|}{$\begin{array}{c}\text { HYDRO-ETHANOLIQUE } \\
\text { EXTRACT }\end{array}$} \\
\hline & 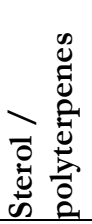 & 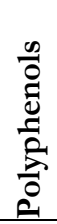 & 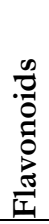 & 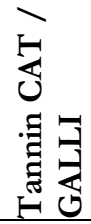 & 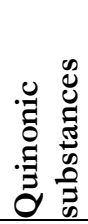 & $\begin{array}{l}\frac{0}{0} \\
\frac{0}{\pi} \\
\frac{\pi}{2}\end{array}$ & 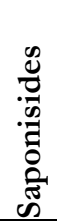 & 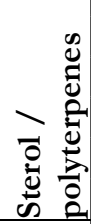 & $\begin{array}{l}0 \\
0 \\
0 \\
0 \\
0 \\
0 \\
0 \\
0 \\
0 \\
0\end{array}$ & 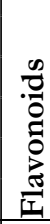 & 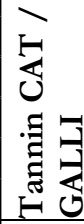 & 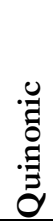 & $\begin{array}{l}\frac{0}{0} \\
\frac{0}{0} \\
\frac{\pi}{3} \\
\frac{3}{2}\end{array}$ & 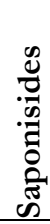 \\
\hline Adenia lobata (JACQ) & + & + & + & + & - & + & + & + & + & + & + & - & + & \\
\hline $\begin{array}{l}\text { Afromonum melegueta } \\
\text { (K.SCHUM) }\end{array}$ & + & + & + & + & - & + & - & + & - & + & - & - & + & - \\
\hline Alstonia boonei (De Wild) & + & - & - & + & + & + & + & + & - & - & + & + & + & - \\
\hline Annona senegalensis (PERS) & + & + & + & + & - & + & + & + & + & + & + & - & + & - \\
\hline $\begin{array}{l}\text { Anthocleista djalonensis } \\
\text { (AFZEL) }\end{array}$ & + & + & + & + & - & + & + & + & + & + & + & - & + & - \\
\hline Blighia sapida (K.D. KOENIG) & + & + & + & + & - & + & + & + & + & + & + & - & + & - \\
\hline Casia sieberiana (DC) & + & + & + & + & - & - & + & + & + & + & + & - & - & - \\
\hline Ceiba pentandra (L.GAERTN) & + & + & + & + & - & + & + & + & + & + & + & - & + & - \\
\hline $\begin{array}{l}\text { Distemonanthus benthamianus } \\
\text { (BAILL) }\end{array}$ & + & + & + & + & - & + & + & + & + & + & + & - & + & - \\
\hline $\begin{array}{l}\text { Grifflonia simplicifolia (DC } \\
\text { BAILL) }\end{array}$ & + & + & + & + & - & + & + & + & + & + & + & - & + & - \\
\hline $\begin{array}{l}\text { Harungara madagascariensis } \\
\text { (LAM) }\end{array}$ & + & + & + & + & - & + & + & + & + & + & + & - & + & - \\
\hline $\begin{array}{l}\text { Holarrhena floribunda( } L . \\
\text { PROTA) }\end{array}$ & + & + & + & + & - & + & + & + & + & + & + & - & + & - \\
\hline Jatropha grosssypiifolia.L & + & + & + & + & - & + & + & + & + & + & + & - & + & - \\
\hline Justicia & + & + & - & + & - & + & + & + & + & + & + & - & + & - \\
\hline $\begin{array}{l}\text { Khaya senegalensis (DESR A. } \\
\text { JUSS) }\end{array}$ & + & + & + & + & - & + & + & + & + & + & + & - & + & - \\
\hline Kigelia africana (PROTA) & + & + & & + & + & + & + & + & + & + & + & + & + & - \\
\hline Morinda lucida $L$ & + & + & + & + & + & - & + & + & + & + & $+/-$ & + & + & - \\
\hline Nauclea latifolia $L$. & + & + & + & + & - & + & + & + & + & + & + & - & + & - \\
\hline Parquetina nigrescens (ALZEL) & + & + & - & + & - & + & + & + & + & + & + & - & + & - \\
\hline Solanum torvum $\mathrm{Sw}$. & + & + & + & + & - & + & + & + & + & + & + & - & + & - \\
\hline $\begin{array}{l}\text { Spathodea campanulata } \\
\text { (P.Beauv) }\end{array}$ & + & + & + & + & - & + & + & + & + & + & + & - & + & \\
\hline Terminalia catapa $L$ & + & + & + & + & - & + & + & + & + & + & + & - & + & - \\
\hline Xylopia aethiopica (DUM) & + & + & & - & + & - & + & + & + & + & + & - & - & - \\
\hline $\begin{array}{l}\text { Zanthoxylum gilletii (DE } \\
\text { WILD) }\end{array}$ & + & + & + & + & - & + & + & + & + & + & + & - & + & \\
\hline Zanthoxylum leprieuri (GUI) & + & + & + & + & - & + & + & + & + & + & + & - & + & - \\
\hline Zingiber officinale (Rosc) & + & + & + & + & - & + & + & + & + & + & + & - & + & - \\
\hline
\end{tabular}

\section{$5 \quad$ CONCLUSION}

The ethnomedicinal investigations conducted out in the eastern of Côte d'Ivoire, in the Indenié-Djouablin region show that 26 species of plants are used by traditional healers to manage sickle cell disease. The drugs (bulb, bark of stem, leaves, flowers, fruits and seeds) are used to make up medication recipes mostly by decoction. There are 3 modes of administration: oral, cutaneous and enema. Drinking is the most used mode of administration. The chemical screening performed on the aqueous and alcoholic extracts of 26 plants species revealed 
the presence of alkaloids, saponins, total polyphenols, flavonoids, tannins, quinones, terpenes and steroids. Phenolic and triterpenes compounds were reported to display antisickling activity in vitro. Some pharmacological information indicate the valid use of the studied

\section{ACKNOWLEDGEMENTS}

The authors would like to thank the Laboratoires de Biologie et Santé de l'UFR des biosciences et de pharmacognosie de L'UFR des Sciences Pharmaceutiques et Biologiques de l'Université Félix Houphouet Boigny of Cocody as well as

\section{REFERENCE BIBLIOGRAPHIQUE} Akakpo-Akue J., Kplé Tatiana KM., Yapo Crezoit A., Fofié Y., Kra A M., Tolo DA. and N'Guessan JD. 2018. In vitro antisickling activity of the aqueous extract of a combination of three plants: Jatropha grossypiifolia, Justicia secunda and Parquetina nigrescens from East Côte d'Ivoire. Journal of Pharmacy and Biological Sciences, 13 (6): $41-48$

Amujoyegbe OO., Idu M., Agbedahunsi J.M. and Erhabor J.O. 2016, Ethnomedicinal survey of medicinal plants used in the management of sickle cell disorder in Southern Nigeria. Journal of Ethnopharmacology185 347-360

Béné K., Camara D., Fofié N’GBY., Kanga Y., Yapi AB., Yapo YC., Ambe SA. and Zirihi GN. 2016. Étude ethnobotanique des plantes médicinales utilisées dans le Département de Transua, District du Zanzan (Côte d'Ivoire). Journal of Animal \&Plant Sciences, 2016. Vol.27, Issue 2: 4230-4250

Békro YA., Békro JA., Boua BB., Tra BF. and Ehilé EE. 2007. Etude ethnobotanique et screening phytochimique de Caesalpinia benthamiana (Baill.) (Caesalpiniaceae). Rev. Sci. Nat. ; 4 : 217 225.

Bindon, J. 2004. Natural Selection and Adaptation: Sickle Cell. [Online] Available: plants by traditional healers in the eastern of Côte-d'Ivoire, to fight sickle cell anaemia. However, further research is needed to study the toxicity, to determinate and isolate the plants active chemical compounds and understand their pharmacological modes of action.

the Département de Biologie Végétale de l'UFR des Sciences Biologiques, Université PéléforoGbon-Coulibaly, for their availability and assistance in carrying out this work.

http://www.as.ua.edu/ant/bindon/ant 475/Sicklecell/Sicklecell.pdf

Chikerie PC. 2011. Sodium metabisulfite-induced polymerization of sickle cell hemoglobin incubated in the extracts of three medicinal plants (Anacardium occidentale, Psidium guajava, and Terminalia catappa) Pharmacogn Mag, 7(26):126-32.

Elekwa, I., Monanu M.O. and Anosike E.O., 2005. In vitro effects of aqueous extracts of Zanthoxylum macrophylla roots on adenosine triphosphatases from human erythrocytes of different genotypes.Biokemistri, 17(1): 19-25.

Fall AB, Vanhaelen-Fastré R, Vanhaelen M, Lo I, Toppet $\mathrm{M}$ and Ferster A, 1999. In vitro anti-sickling activity of a rearranged limonoid isolated from Khaya senegalensis. Planta Med.; 65:209-12

Fatokun OT., Agbedahunsi JM. and Elujoba AA., 2015. Antisickling Activities of Some Nigerian Medicinal Plants. Nigerian Journal of Natural Products and Medicine. Vol 19: 92-100eISSN: 1118-6267

Fujita, T., E. Sezik, M. Tabata, E. Yesilada, G. Honda, T. Tanaka, and Y. Takaishi. 1995. Traditional medicine in Turkey VII: folk medicine in middle and west Black Sea regions. Economic Botany 49(4):406-422.s 
Galactéros F. 1997. La drépanocytose. Engl J Med; 337: 762-9. 4

Gbadamosi IT., SB. Adeyemi AA., Adeyemi and Moody JO, 2012a. In vitro antisickling activities of two indigenous plant recipes in Ibadan, Nigeria. International Journal of Phytomedicine, 4: 205-211.

Gbadamosi IT., 2015. An Inventory of Ethnobotanicals Used in the Management of Sickle Cell Disease in Oyo State, Nigeria. Botany Research International, 8 (4): 65-72

Ghedira K. 2005. Les flavonoïdes: structure, propriétés biologiques, rôle prophylactique et emplois en thérapeutique. Phytothérapie 3, 162-169 https://doi.org/10.1007/s10298-0050096-8

Girot R, Bégué P and Galacteros F. 2003. La drépanocytose. John Libbey Eurotext, Paris. 319.

Imaga NO, Gbenle GO, Okochi VI, Adenekan $\mathrm{SO}$, Edoeghon SO and Kehinde MO, 2010. Anti-sickling and toxicological profiles of leaf and stem of Parquetina nigrescens L. J Med Plants Res; 4:639-43.

Koffi N’Guessan, Beugré Kadja, Guédé N. Zirihi, Dossahoua Traoré and Laurent Aké-Assi. 2009. Screening phytochimique de quelques plantes médicinales ivoiriennes utilisées en pays Krobou (Agboville, Côte-d'Ivoire). Sciences \& Nature: 6(1): 1-15

Martin, G.J. 1995. Ethnobotany. A "People and Plants" Conservation Manual. World Wide Fund for Nature. Chapman \& Hall, London

Misaki W. 2008. Bone marrow transplantation (BMT) and gene replacement therapy (GRT) in sickle cell anaemia. Niger. J. Med.; 17(3): 251-256.

Mpiana PT, Tshibangu DS, Shetonde OM, Ngbolua KN. 2007. In vitro antidrepanocytary activity (anti-sickle cell anaemia) of some Congolese plants. Phytomedicine; 14(2-3):192-5.
Mpiana PT., Ngbolua KN., Mudogo V., Tshibangu DST., Atibu EK., Mbala BM., Kahumba B., Bokota MT. and Makelele LT. 2012. The Potential Effectiveness of Medicinal Plants used for the Treatment of Sickle Cell Disease in the Democratic Republic of Congo Folk Medicine: A Review. Progress in traditional folk herbal medicine. Daya Publishing House, New Delhi. 1: pp1-11

N'Guessan K., 2008. Plantes médicinales et pratiques médicales traditionnelles chez les peuples Abbey et Krobou du Département d'Agboville (Côted'Ivoire). Thèse de Doctorat ès Sciences Naturelles. Université de CocodyAbidjan, U.F.R. Biosciences, Laboratoire de Botanique. $N^{\circ}$ d'ordre: 561 / 2008, $235 \mathrm{p}$.

Nemlin J. and Brunel JF. 1995. - Fascicule de Travaux Pratiques de Matière Médicale (3ème année). Université Nationale de Côte-d'Ivoire. Faculté de Pharmacie. Département de Pharmacognosie. Laboratoire de Phytologie, $47 \mathrm{pp}$.

Ngbolua KN., Rafatro H., Rakotoarimanana H., Ratsimamanga Urverg S., Mudogo V., Mpiana PT. and Tshibangu DST. 2011a. Pharmacological screening of some traditionally-used antimalarial plants from the Democratic Republic of Congo compared to its ecological taxonomic equivalence in Madagascar. International. Journal. Biological and Chemical. Sciences. 5 (5):1997-1804

Ngbolua KN., Rakotoarimanana H., Rafatro H., Urverg-Ratsimamanga S., Mudogo V., Mpiana PT. and Tshibangu DST. 2011b. Comparative antimalarial and cytotoxic activities of two Vernonia species: $V$. amygdalina from the Democratic Republic of Congo and $V$. cinerea subsp vialis endemic to Madagascar. International. Journal. Biological and Chemical. Sciences. 5(1):345-353.

Ngbolua KN, Rafatro H, Rakotoarimanana H, Mudogo V, Mpiana PT and Tshibangu 
DST 2015. In vitro anti-erythrocyte sickling effect of lunularic acid of natural origin. International Blood Research \& Reviews; 4(3):1-6.

OMS, 2010. Drépanocytose: une stratégie pour la région africaine de l'OMS. Rapport du Directeur régional $3 \mathrm{p}$.

Ouattara D., Kouame D., Siebre MS., Cisse A. and N'guessan KE. 2016. Diversité floristique et usages des plantes dans la zone soudanienne du Nord-ouest de la Côte d'Ivoire. Journal of Animal \&Plant Sciences (JAPS), 31 (1): 4815-4830

Sawadogo D., Tolo-Dilkébié A., Sangaré M., Aguéhoundé N., Kassi H., and Latte T 2014. Influence of the Clinical Status on Stress Reticulocytes, CD 36 and CD 49d of $\mathrm{SSFA}_{2}$ Homozygous Sickle Cell Patients Followed in Abidjan. Volume |Article

ID 273860 | 6 pages http://dx.doi.org/ $10.1155 / 2014 / 273860$

Thuret I, Sarles J, Merono F, Sarles J., Merono F., Suzineau E., Collomb J., Lena-Russo D., Levy N., Bardakdjian J. and Badens C., 2010. Neonatal screening for sickle cell disease in France: evaluation of the selective process Journal of Clinical Pathology; 63:548-551.

Tolo-Diebkile A. Kouassi KG., Danho NC., Sawadogo D., Kouakou B., SiransyBogui L., Sékongo YM., N’Dhatz E., Méité N., Ayémou R. and Sanogo I 2010. Drépanocytose homozygote chez l'adulte ivoirien de plus de 21 ans. Cahiers Santé Volume 20, N 2 : 63-67

Tshibangu DST, Shode FO, Koorbanally N, Mudogo V, Mpiana PT and Ngbolua $\mathrm{KN}$ 2011. Antisickling triterpenoids from Callistemon viminalis, Meulaleuca bracteata var. Revolution Gold Sysygium guineense and Syaygium cordatum. The 14th NAPRECA Symposium and AAMPS Ethnoveterinary Medicine Symposium 8th-12th August International Centre for Insect Physiology and Ecology (ICIPE):
Kasarani, Nairobi, Kenya, 296-300 (YS 27).

Tshilanda DD, Onyamboko DNV, Babady PB, Ngbolua KN, Tshibangu DST and Dibwe EF 2015. Anti-sickling Activity of Ursolic Acid Isolated from the Leaves of Ocimum gratissimum L. (Lamiaceae). Nat. Prod. Bioprospect: 5:215-221.

Uwakwe AA. and Nwaoguikpe RN., 2008. In vitro anti-sickling effects of Xylopia aethiopia and Monodora myristica. J Med Plant Res; 2:119-24.

Zirihi G., Kra AKM., and Guede-Guina F. 2003.- Évaluation de l'activité antifongique de Microglossa pyrifolia (Lamarck) O.Kantze (Astéracée) «PYMI » sur la croissance in vitro de Candida albicans, Revue de Médecine et pharmacie Afrique, 17: 11 -18. 